Research Report No. 20/2009

\title{
Extensive Income and Value of the Firm: Who Gets What?
}

Shyam Sunder

Follow this and additional works at: http://digitalcommons.osgoode.yorku.ca/clpe

\section{Recommended Citation}

Sunder, Shyam, "Extensive Income and Value of the Firm: Who Gets What?" (2009). Comparative Research in Law \& Political Economy. Research Paper No. 20/2009.

http://digitalcommons.osgoode.yorku.ca/clpe/133 


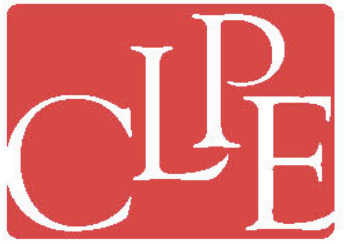

\section{Comparative Research in Law \& Political Economy}

\section{Shyam Sunder}

\section{Extensive Income and Value of the Firm: Who Gets What?}

EDITORS: Peer Zumbansen (Osgoode Hall Law School, Toronto, Director, Comparative Research in Law and Political Economy, York University), John W. Cioffi (University of California at Riverside), Nassim Nasser (Osgoode Hall Law School, Toronto, Production Editor) 

CLPE Research Paper 20/2009

Vol. 05 No. 03 (2009)

Shyam Sunder

\title{
EXtensive Income and VAlue of The Firm: Who Gets What?
}

\begin{abstract}
In the neoclassical model of the firm, value surplus of the firm is assumed to accrue to its owners. Contract model suggests a distribution of the surplus among various agents depending on the imperfections of the markets in which they transact with the firm. If the share of the surplus to an agent declines with the perfection of the market in which he transacts, shareholders should be expected to get only a small piece of the pie, violating the neoclassical assumption. The paper explores an extensive value concept and its measurement for firms. It also examines the implications of extensive value for what we do and do not know about the consequences of corporate mergers and acquisitions.
\end{abstract}

Keywords: factor income distribution, extensive value, surplus

JEL classification: D33, L21, M21, M41

Shyam Sunder

J. L. Frank Professor of Accounting, Economics and Finance

Yale School of Management

135 Prospect St. New Haven CT 06511 USA

shyam.sunder@yale.edu 


\title{
EXtensive InCome And VALue Of The Firm: Who Gets What?
}

\author{
Shyam Sunder ${ }^{*}$
}

\section{INTRODUCTION}

We can think of firms and other organizations as alliances among people embedded in the larger matrices of society and natural environment. Their value depends on the perspective we choose. We examine the value of the firm from alternative perspectives and compare it to the benchmark concept of shareholder value. We also explore the accounting, managerial, and policy implications of these values. Social accounting under the label of corporate social responsibility or CSR came into vogue over the last quarter of the twentieth century. What are its links to these values?

Simon (1952) compared the neoclassical economics and organizational views of the firm. Under the organizational or contract-theoretic view, based on Rousseau's social contract and developed by Barnard (1936), Simon (1947), and Cyert and March (1963), a firm is a set of contracts or alliances among agents. Each agent contributes factors of production to the firm, and receives compensation or inducement in the form of cash or other resources in exchange. Each agent chooses to participate in the firm if the value of inducements offered by the firm exceeds the opportunity cost of his resource contributions. All agents are located symmetrically in this simple scheme, labeled O-theory (for organization theory) in Simon (1952).

In the neoclassical economic theory, labeled F-theory in Simon, a firm is seen as an instrument of the entrepreneur or owner. In models of perfect or imperfect competition, all agents, other than the owner, are considered passive in the sense that their behavior can be well represented by their respective functions. The owner, being the only active decision maker, works with production, supply and demand functions to maximize the value of the firm he owns. Value to the owner - the net present value of future benefits flows between the shareholder and the firm discounted at the owner's opportunity cost of capital - is the value of the firm. If the present value is zero, investment in the firm creates no value for the shareholder relative to the next best investment opportunity available to him.

Financial accounting reports and some aspects of national income statistics are directed to, and are based on the value to the owner. Many approximations and compromises are made in moving from the economic concept to concrete measurements to produce financial and nonfinancial data, which we return to later. There have been lengthy debates about alternative

\footnotetext{
* Shyam Sunder is the James L. Frank Professor of Accounting, Economics, and Finance at the Yale School of Management, and Professor in the Department of Economics. Sunder is an accounting theorist and experimental economist. His research contributions include financial reporting, dissemination of information in security markets, statistical theory of valuation, design of electronic markets, and experimental finance and experimental macroeconomics.
} 
specifications of the objective(s) of the firm. Still, shareholder value reigns supreme in theory, data, accounting practice, and normative discussions of corporations.

In contrast, contract theory of the firm treats all participating agents symmetrically. Agents contribute factors; the firm uses its production technology to convert them into products, and distributes them as inducements to the agents. For example a simple manufacturing firm with owner, labor, and customer as three classes of agents, collects capital, labor and cash as factors; and distributes dividends, wages, and products as inducements to them.

Standard assumption in micro-economic theory of the firm is that the firm maximizes its profit by choosing its technology, production, and marketing. For a given output, factor costs (other than the cost of equity) are minimized. If the entrepreneur/owner makes all the decisions cost minimization is, at least, a credible possibility. As decision-making is delegated to a hired manager who has asymmetric access to information and goals of his own cost minimization does not survive, even as a theoretical possibility. The cost to the entrepreneur is the compensation sought by the manager who makes the decisions. As more levels of management are added to the corporate hierarchy, each with his own ego, goals, and asymmetric access to special information; cost minimization recedes to become a remote ideal. In agency theory this ideal is labeled the first-best solution; and the theoretical impossibility of attaining it gives rise to a new, second-best, benchmark that allows each participant a slice of the surplus or rent (compensation in excess of opportunity cost) of his own, in equilibrium contract with the superior. This excess is the income of the respective agent.

Sunder (1997, pp. 65-66) draws attention to the income streams-inducements less contributions - each agent receives from the firm. He attributes the special status of the shareholder income as the income of the firm (and the associated capitalized shareholder value as the value of the firm) to the lowest priority shareholders have as residual claimants to a firm's resources. The residual character imparts special information and contractual properties to the shareholder income. It carries, for example, information about the continued viability of the contract set of the firm.

The special importance of income to shareholders need not diminish the significance of income to the other agents. Corporations influence the lives of most people not only because they may own shares, but also because they may be customers, employees, vendors, neighbors, or citizens. These influences take many forms - direct and indirect, immediate and long run, local and global, through priced market transactions and externalities. Tracking these income (or loss) streams from corporations to various agents in society can affect both private as well as public decision-making. The work of Matsumoto (2007) on accounting for distribution of wealth in Japanese corporations is a good example. An intensive effort has been made over the past quarter century to broaden corporate reporting to include some of these elements under the label of social accounting (see, for example, AAA 1972, 1974; Estes 1972, 1976; Seidler and Seidler 1974 and Zadek and Tuppen 2000). We briefly review this literature before returning to discuss the value of the firm. 


\section{Social Accounting}

Social accounting by business and other organizations is an attempt to measure and report their efforts, achievements, and impact an "social" dimensions. Socioeconomic accounting, social responsibility accounting and social audit are used synonymously. Energy conservation, minority hiring, environmental preservation, and support of community organizations are examples of such dimensions. Appendix A outlines a list of dimensions that may be covered, although rarely at once, in social accounting. Internet links to many such accounts are easily available. Social accounting reports can be descriptive, and may include financial or nonfinancial data. They may also include data and analysis of non-priced externalities; justification for social expenditures being in the long-run interests of the shareholders; development of acceptable and reliable ways of quantifying hard to measure costs and benefits; and for some public organizations, cost-benefit analyses of social interventions and policies.

Interpretation of "social" in social accounting, as illustrated in Appendix A, is construed narrowly. It leaves out production, sale, and distribution of goods and services, and employment. The intent here is not that these activities have no social impact or relevance. Instead, social accounting tends to focus on non-priced or unrecorded consequences of organizational activities with the presumption that the priced activities are already included in regular financial reports. A better interpretation of social accounting, one may argue, should be a comprehensive picture that includes priced as well as non-priced consequences.

Implementations of social accounting place the responsibility for production of information on managers of the firm (see Elliott 1973). Managers can report only what they know. For many kinds of social consequences, managers have no such informational advantage. Information is inherently dispersed among agents in society; and it is difficult for one to know the preferences, knowledge, opportunity sets and certain actions of others. Social accounts prepared by corporate managers, or any other single party, suffer from this inherent limitation of information accessible to that party. When well-functioning markets exist, they bring the dispersed information together, incorporate it in price, and make it available to all (Hayek 1945). Since social accounting covers areas in which markets are weak or nonexistent, such solutions are not available in social accounting.

A second problem of corporate social accounting is that most proposals have taken the perspective of the firm, instead of the members of society-the principals. The traditional measure of value in business - value to the shareholder - and accounting directed to that end, have worked well because the concept and its implementation take the perspective of a principal. Attempts to broaden the shareholder perspective to a broader set of agents have been spent on descriptive details of corporate activity, giving social accounting a fuzzy image. We may do better assessing corporate value creation from the perspective of the relevant agents. 


\section{VALUE OF THE FIRM}

All participants in a firm receive, or expect to receive, a stream of income-inducements less contributions - from the firm. Accordingly, value of the firm to the owner is but one component of the value of the firm to all its participants. The concept of value that corresponds to the contract model is the difference between the inducements distributed from the firm to various agents, and the opportunity cost of resources contributed by them to the firm. In other words, value of the firm is the sum of surplus the firm gives to all agents. This note defines and explores the properties and implications of this extensive concept of firm's value.

\section{A. VALUe to InVESTORS}

Setting market imperfections aside, value of a firm to a prospective shareholder is the difference between the discounted present value of cash returns and the cash investments. The discount rate is the opportunity cost of capital for the investor. If the internal rate of return from the prospective investment is equal to the opportunity cost of capital, the value of the investment is zero; if IRR exceeds the opportunity cost of capital, this value is positive. Presumably, investors would not make the investment when the IRR is lower. Skillful investment consists of finding investment opportunities where IRR is greater than the opportunity cost of capital.

After an investor buys the shares of a firm, the purchase price becomes sunk cost. The value of this investment now is the present value of cash returns from the shares discounted at the opportunity cost of capital. The value of the investment to prospective shareholder(s) is the cash return net of cash investments; value to an existing shareholder is just the gross cash return, appropriately discounted. Stock prices are determined in the market place through interaction of demand and supply based on these individual shareholder values.

Much of financial reporting is focused on the investor's point of view-income to investors, and equity of investors. We can apply the same point of view to other agents in the firm, and then return to aspects of accounting that address, or could address, those points of view.

\section{B. VALue Of THE Firm to Its Customers}

Value of the firm to a customer can be evaluated in a manner parallel to the value to a prospective investor. The customer "invests" in the firm in the form of search, learning, negotiation, payments including advance payments, and settlement of any disputes. These investments are made in the expectation that the present value of benefits generated from the goods or services received from the firm, discounted at the opportunity cost of the customer's 
capital, will exceed the opportunity of costs of resources invested. Strictly speaking, this reckoning includes not only the transaction on hand, but also the consequences of this transaction for resource flows associated with the subsequent transactions. A satisfactory transaction, for example, may cut the time to search, learn, and negotiate, frequency of disputes, and perhaps even the price associated with subsequent transactions. These consequences, lumped together as customer goodwill, are reckoned in the "investment" decision associated with the transaction at hand.

The customer transacts with the firm if the reckoning of resource flows shows the benefits of the transaction exceeds the opportunity cost of necessary sacrifices. The present value of this excess is the value of the firm to the customer. This value is also the customer's share of the surplus generated by the firm. If the customer pays the firm in advance, the value of the firm to the customer increases by the amount of the advance (analogous to the change in the value of the firm to prospective and existing shareholders).

If multiple firms create conditions of perfect competition in the product market, a customer's opportunity cost of buying from firm A is forgoing an identical product sold by its competitors at identical price. Therefore, the consumer's share of the surplus from buying from firm A instead of its competitors is zero. An individual firm therefore creates zero value for the customers in a perfectly competitive market, and customer loyalty disappears. To create value for customers, firms differentiate themselves by offering products that their competitors don't offer.

Yet, a competitive industry as a whole may generate a positive surplus for its customers. In absence of its product, the customer may have to buy a less satisfactory substitute, possibly at a higher price. Therefore, the sum of customer value generated by individual firms in an industry is less than or equal to the sum of customer value generated by the industry as a whole. Similar argument is applicable to factor markets we discuss next. 


\section{VAlue of the Firm to Its Vendors}

This value is defined analogously to the firm's value to its customers, except that the vendors' contributions take the form of goods and services, and they tend to receive cash from the firm. If the market for the factor is competitive, an individual firm generates no value for a vendor who can always sell his resource at the same price elsewhere. Following the argument from the preceding section, all buyers of the resource may yet, collectively, create value for the vendor.

\section{VALUE OF THE FiRM TO ItS EMPLOYEES}

Value to the employee can be evaluated in a similar manner. In this reckoning, resources expected by an employee include: wages, benefits, satisfaction, relationships, human skills, and reputation over the employment horizon. Employee's opportunity cost of skills and effort contributed to the firm is subtracted from the value of resources received to arrive at the value of the firm. Again, unless the expectation of this value is non-negative (benefits are not exceeded by the opportunity cost), there is no reason for the employee to take the job. In a perfectly competitive job market, an individual employer generates no surplus for the employee, making him indifferent among competing employers.

\section{E. VALUe OF THE Firm to THE GOVERnMENT}

Governments at various levels contribute resources to firms, mostly in the form of non-priced public services such as health, education, public safety, courts, laws, etc. They also receive resources from the firms in the form of taxation on corporate income, payrolls, property, sales, vehicles, etc. In addition, governments contribute resources to firms in the form of priced goods and services such as highway tolls, passports, and fishing licenses. The value of a firm to the government can be reckoned as the sum of values from priced and non-priced services. Since priced services are mostly private goods, value to the government of providing such services to a firm can be handled analogously to valuation by other vendors. Valuation of non-priced services, being mostly public goods, is an important challenge we shall discuss in the section on externalities. When a government receives a net contribution from a firm (taxes and fees exceed the opportunity cost of resources spent on providing services to the firm), the firm has a positive value to the government. 


\section{F. VALUE OF THE FIRM TO THE COMMUNITY}

Community, like governments, can be considered at different levels-local, national or global. Most exchanges between firms and community take the form of positive and negative externalities. Firms may attract visitors, name recognition, and related businesses to its neighborhood, as well as add pollution and congestion. They may also contribute directly to civic and charitable organizations. Value of the firm to the community is the net result of all these resource flows. It is often the subject of social accounting. We will return to the difficult problems of estimating externalities in a later section.

Value of the firm is the sum of its value to all its participants - the excess of total resources generated over the opportunity costs of all resource inputs. Much has already been written about the shareholder value. We shall focus our attention on the sum, its other components, and implications for accounting and management.

\section{Measurement of VAlue}

J. M. Clark (1936) points to three fundamental challenges to determining the value of private enterprise:

One is that the problem of the collective efficiency of private enterprise involves quantities and qualities, of which actual market prices are not the only measure, and, I would add, some of which command no market price at all under present conditions, although with changes in law and custom, they might perhaps come to command one. Another is that measures of value which may be less exact than those of the market are also much more fundamental. And a third is that our most fundamental concepts would be independent of institutions of competitive exchange; they should be such as would hold even in a socialistic economy (p. ?).

Resources flow to and from the firm under a variety of conditions. Some resources, of which capital is perhaps is the best example, have well organized liquid markets that approach perfection (see Sunder 1999a, 1999b, 2000). Price is easy to observe and approximates opportunity cost well. At the other extreme, markets do not exist for clean air and safe streets, raising difficult problems for value measurement. Let us explore the links between market conditions and measurement of firm value. 


\section{A. Markets AND VAlue of THe Firm}

If the markets for all factors of production and for all products were perfect, the value of the firm to all participants, and therefore its total value, would be zero. The prices prevailing in the respective markets would be the opportunity costs for the agents. In a perfect labor market, there is only one wage available for the skills an employee has to offer, and this wage is available to him from many different firms. Thus a perfect market makes sure that the value of the employee's wage is equal to the opportunity cost making the value of the firm to the employee zero. Similarly, if the market for the product of a firm were perfect, one price for the product would prevail, driving the value of the firm to the customer to zero. Similar arguments would apply to other agents, including the shareholders.

Existence of value for any agent requires the presence of imperfection in the respective product or factor markets. While perfection is the tendency of competitive markets under classical conditions, it is not the goal of any agent. Agents seek value for themselves, and it can only be found in crevices of market imperfections. As agents exploit any imperfections they may discover, they diminish or eliminate the imperfections in the process of seeking profits. In search of profits, agents not only seek out but also create market imperfections.

Even in otherwise perfect markets, agents specialize to create little local monopolies of their own, and seek to exploit them in bargaining with others. A special skill, special knowledge, special product, special service, patent, are all ways to creating and exploiting such monopolies. Creation of each monopoly makes the market a little less perfect, opening a gap between the sale price and opportunity cost of the resource. This gap is the value. Agent's exploitation of the value created through specialization begins to close the gap, and diminishes the value for the future. To stay ahead, the agent must continually and dynamically seek other ways of distinguishing the resource he/she has to offer to create new values, exhausting it in the process of capturing it. Creating value is more like a treadmill than a ski lift.

Of course, markets are hardly perfect. Even without conscious and explicit efforts to specialize and create value, various kinds of transaction costs create gaps in which value exists. My existing job retains its value for me because it is costly for me to find another job that compensates me at the level my skills deserve. I am paid my current compensation because it is costly for my employer to find a worker with even better skills to do the job. The cost of a job search lowers the employee's opportunity cost of keeping the present job; costs of search, recruitment, and training make it cheaper for my employer to retain my services.

Values rise as markets become less perfect. In more perfect markets, valuation is easier to do, but there is less to value. In extreme cases, markets disappear altogether, providing no assistance in valuation. 


\section{B. EXTERnAlities in VALUe of THE Firm}

Difficult problems of measurement arise when goods and services are not priced even in relatively imperfect markets. With zero marginal cost and impossibility of excluding nonpayers from their benefits, pure public goods are inherently incapable of supporting a price. Most organizations produce and consume some public goods. Building an auto assembly plant in a rural area improves skills, employment, retail stores, property values, roads, entertainment and public schools. They are called externalities because there is no direct way for the firm to extract a price from individuals who benefit from these public goods. The extensive concept value of the firm includes the value of these benefits bestowed on individuals or the community.

Pollution and congestion are examples of negative externalities a firm may impose on others without compensating them. This imposition is counted negatively in valuing the firm from the point of view of such uncompensated parties. The National Accountants Association's social performance measures included in Appendix A is a more complete listing of positive and negative externalities.

\section{DifFiculties of VALUing EXTERnALities}

Absent transaction prices and externalities need alternative methods for valuation. As an example, consider vans provided by the firm to transport employees between nearby subway stations and the factory free of charge. Cost of the service to the firm, say X, is easily measured, and treated as an expense in calculating net income to the shareholders. If we stop here, the extensive income of the firm to all agents is understated because net income to shareholders ignores some of the benefits of the service to agents other than shareholders. A part of benefits of the service flows back to the shareholders in the form of lowered costs of employee parking, absenteeism, fatigue, etc. This benefit, say $\mathrm{Y}_{1}$, to the shareholders is included in net income through lowered labor costs and higher productivity.

A second part of the benefit accrues to the employees in the form of avoided cost of alternative transportation, saving in commuting time, fatigue, etc. These benefits, say $\mathrm{Y}_{2}$, must be added to other components of compensation in calculating their income stream from employment. The saving in the cost of alternative transportation can be estimated reasonably well in terms of money if there is a market for such services. Savings in time, fatigue, etc., vary across people, making it difficult for the firm to come up with reasonable estimates. Benefits of less fatigue may be subjective, difficult to estimate quantitatively, and even more difficult to state in terms of money. In any case, there is little chance that the firm can come up with a better estimate of $\mathrm{Y}_{2}$ than the employees who use the transportation service. 
A third part of the benefit of the transportation service accrues to fellow commuters by train (lowering the cost of mass transportation through higher utilization), commuters by road (less rush hour traffic), transport companies (additional customers), local government (less spending on roads and parking), and fellow citizens (less pollution). One could take this argument further and identify progressively diffuse second and third order consequences of the transportation service.

Perhaps it is best to group these agents together into "community" and estimate the value of the firm to this group by identifying various positive and negative externalities in a lump sum. Tools of social cost-benefit analysis are widely employed for this purpose, though rarely in social accounting reports produced by corporations. Being based on judgments and assumptions, estimates can be quite sensitive to the interests of the party who prepares them. Cost-benefit analyses produced to support or oppose public expenditures on stadiums for sports teams are a good example of this problem.

What is the appropriate discount rate for valuing the net cost-benefit stream to the community? Social rate of discount, lower than private discount rates, is used for this purpose. Voluminous literature already exists on the topic (see Caplin and Leahy 2000).

\section{Mergers, Acquisitions And Corporate Value}

Consider the debates surrounding the consequences of corporate mergers and acquisitions. There have been numerous studies (see Ruback 1983; also literature reviews by Jensen and Ruback 1983, and Jarrell, Brickley and Netter 1988) of the effect of mergers and acquisitions on shareholder value. On balance, findings of stock market event studies, predicated on the assumption of market efficiency, favor a transfer of wealth from the acquiring firm shareholders to the shareholders of the acquired firms; and a small gain, at most, in shareholder value overall. Scherer (1988) on the other hand concludes that, while some mergers may increase shareholder value and others decrease it, on the whole the effect of mergers on shareholder value is about even.

A interesting feature of these debates, especially those oriented to public policy, is that they are focused on the consequences of mergers and acquisitions for shareholder value; only occasionally including the value to the holders of debt securities and taxes to the government (see Dhaliwal and Sunder 1988). Effects of these mergers on labor are rarely examined (see Brown and Medoff 1987 and Shleifer and Summers 1987 for two exceptions) and effects on other classes of agents are ignored.

One way of making sense of this state of affairs is that the debaters assume the standard neoclassical firm perspective in which all factors of production except the equity capital earn their opportunity costs from the firm, and get no share in the surplus generated by the firm. The economic profit accruing to the suppliers of all these other factors of production being zero, the 
value of the firm for them is also zero; both before as well as after the merger or acquisition. Under this perspective, changes in the value of the firm are confined to the shareholder value; therefore it makes sense to carry on the debate on consequences of mergers on the basis of empirical evidence on shareholder value alone.

But this explanation runs into a difficulty. As we discussed in earlier sections of the paper, agents who transact with the firm through relatively perfect markets for factors or products should expect to get close to their opportunity cost - the price that is well-defined in these markets - and nothing more or less. In the U.S. markets for equity capital are frequently cited to be efficient, at least more efficient than others. If a firm generates a surplus (value of output in excess of the sum of opportunity costs of factors of production), holders of equity capital are least likely to capture any significant piece of the pie. Most of the surplus should end up with the agents who transact in less perfect markets.

Shareholders have the only open-ended contract in the firm; all others are negotiated periodically. Labor, customers and vendors have frequent opportunities to renegotiate the terms of their transactions with the firm, and try to capture a share of the surplus whenever possible. Given the short-term nature of their contracts, they have an option value that the shareholders, tied into long-term contract as a group, lack. Agents with short-term contracts can quit when confronted with having to absorb a negative surplus. Employees with unvested pension benefits and shareholders do not have this option.

This analysis suggests that an assessment of the consequences of mergers and acquisitions require an analysis of not only the shareholder values, but also of values accruing to other participating agents as outlined above. Being tied into an indefinite term contract and imperfections of corporate governance, shareholders may not be able to capture all or even most of the ex post benefits of value-enhancing mergers and acquisitions; these benefits leak out to corporate managers through holes in corporate governance, and to other agents through periodic negotiations under uncertainty and market imperfections. Yet, the shareholders are left holding the bag when a merger turns out to be value depleting. Corporate executives, labor, customers, vendors and the community may capture significant shares in value enhancements from mergers, and bear only a smaller fraction of value depletions. Perhaps we cannot know for sure without careful empirical analysis of extensive value of the firm. 


\section{APPENDiX A}

Excerpted from the Report of National Association of Accountants Committee on Accounting for Corporate Social Performance

IV. Major Areas of Social Performance

Community Involvement

General philanthropy-Corporate support of educational institutions, cultural activities, recreational programs, health and community welfare agencies and similar eleemosynary organizations

Public and private transportation-Alleviating or preventing urban transportation problems, including the provision of mass transportation of employees

Health services-Providing health care facilities and services and the support of programs to reduce disease and illness

Housing-Improving the standard of dwellings, the construction of needed dwellings and the financing of housing renovation and construction

Aid in personal and business problems-Alleviation of problems related to the physically handicapped, child-care, minority businesses, disadvantaged persons, etc.

Community planning and improvement-Programs of urban planning and renewal, crime prevention, etc.

Volunteer activities-Encouraging and providing time for employees to be active as volunteers in community activities

Specialized food programs - The provision of meals to meet the dietary needs of the aged, the infirm, the disadvantaged children, and other groups

Education-The development and implementation of educational programs to supplement those of the public and private schools such as work study programs; and employee service on school boards, school authorities and college university trustee and advisory boards

\section{Human Resources}

Employment practices-Providing equal job opportunities for all persons, creation of summer job opportunities for students, and recruiting in depressed areas

Training programs - Providing programs for all employees to increase their skills, earning potential and job satisfaction

Promotion policies-Recognizing the abilities of all employees and providing equal opportunities for promotion

Employment continuity-Scheduling production so as to minimize lay-offs and recalls, maintaining facilities in efficient operating condition so that they would not have to be abandoned because of deterioration and exploring all feasible alternatives to closing a facility 
Remuneration-Maintaining a level of total salaries and wages plus benefits which is in line with others, in either the industry or community

Working conditions-Providing a safe, healthful and pleasant working environment

Drugs and alcohol-Providing education and counseling for employees to prevent or alleviate problems in these and similar areas

Job enrichment-Providing the most meaningful work experiences practical for all employees

Communications-Establishing and maintaining two-way communication between all levels of employees to secure suggestions, to provide information as to what the company is actually doing and how each department's activities relate to the total corporate activity, and to inform employees' families and friends of corporate activities

Physical Resources and Environmental Contributions

Air-Timely meeting of the law and going beyond the law in avoiding the creation of, alleviating, or eliminating pollutants in these areas

Water-Timely meeting of the law and going beyond the law in avoiding the creation of, alleviating, or eliminating pollutants in these areas

Sound-Timely meeting of the law and going beyond the law in avoiding the creation of, alleviating, or eliminating pollutants in these areas

Solid waste-Disposal of solid waste in such a manner as to minimize contamination, reduce its bulk, etc., and the design of processes and products which will minimize the creation of solid waste

Use of scarce resources-The conservation of existing energy sources, the development of new energy sources, and the conservation of scarce materials

Aesthetics-The design and location of facilities in conformance with surroundings and with pleasing architecture and landscaping

Product or Service Contributions

Completeness and clarity of labeling, packaging, and marketing representationAssurance that labeling and representation as to methods of use, limitations on use, hazards of use, shelf-life, quantity of contents, and quality cannot be misunderstood

Warranty provisions - Adherence to all stated and implied warranties of a product with implementation through timely recalls, repairs or replacements

Responsiveness to consumer complaints-prompt and complete responses to all complaints received

Consumer education-Literature and media programs to keep consumers informed of product and service characteristics, methods and areas of use of products, and of planned product changes and discontinuances

Product quality - Assurance through adequate control— "quality assurance"- that quality is at least equal to what customers may reasonably expect on the basis of company representations 
Product safety-Design or formulation and packaging of products to minimize possibilities of harm or injury in product use

Content and frequency of advertising - Giving full consideration to the omission of any media material which may be adverse or offensive; and the avoidance of repetition to the extent that it becomes repugnant

Constructive research-Orienting technical and marketing research to meet defined social needs and to avoid creating social and environmental problems or to minimize such problems: e.g., energy consumption 


\section{REFERENCES}

American Accounting Association. 1972. "Report of the Committee on Measurement of Effectiveness for Social programs," The Accounting Review, Supplement to Vol. 47, pp. 336-96.

American Accounting Association. 1974. "Report of the Committee on Measurement of Social Costs," The Accounting Review, Supplement to Vol. 49, pp. 98-113.

Asquith, Paul. 1983. "Merger Bids, Uncertainty and Stockholder Returns," Journal of Financial Economics 11:51-83 (April).

Barnard, Chester I. 1936. The Functions of the Executive. Cambridge, MA: Harvard University Press.

Brealey, Richard A., Stewart C. Myers, and Alan J. Marcus. 1995. Fundamentals of Corporate Finance. New York: McGraw-Hill.

Brown, Charles, and James L. Medoff. 1987. "The Impact of Firm Acquisitions on Labor," NBER Working Paper.

Caplin, Andrew, and John Leahy. 2000. "The Social Discount Rate,” NBER Working Paper 7983.

Churchman, C. West. 1971. "On the Facility, Felicity, and Morality of Measuring Social Change," The Accounting Review (January), pp. 30-35.

Clark, John M. 1936. A Preface to Social Economics: Essays on Economic Theory and Social Problems. New York: Farrar and Rinehart.

Cyert, Richard M. and James March. 1963. A Behavioral Theory of the Firm. Englewood Cliffs, N.J.: Prentice-Hall.

Dhaliwal, Dan and Shyam Sunder. 1988. "Mergers, Acquisitions, and Takeovers: Wealth Effects on Various Economic Agents," in Gary Libecap, editor, Advances in the Study of Entrepreneurship, Innovation, and Economic Growth: Corporate Reorganizations Through Mergers, Acquisitions, and Leveraged Buyouts, Supplement 1, 1988, pp. 169190. Greenwich, CT: JAI Press.

Donegan, Jim and Shyam Sunder. 1989. "Contract Theoretic Analysis of Off-Balance Sheet Financing," Journal of Accounting, Auditing and Finance. Vol. ???, pp. .

Elliott, Robert K. 1973. "Measuring the Quality of Life," World, (Spring). Peat, Marwick, Mitchell \& Co. Reprinted in Seidler and Seidler, eds. Social Accounting: Theory, Issues and Cases. New York: John Wiley, 1975.

Estes, Ralph W. 1972. Accounting and Society. New York: John Wiley.

Estes, Ralph W. 1976. Corporate Social Accounting. New York: John Wiley.

Hatfield, Henry Rand. 1924. “An Historical Defense of Bookkeeping," Journal of Accountancy, Vol. 34:4 (April), pp. 241-253. Reprinted in W.T. Baxter and Sidney Davidson, eds. Studies in Accounting. London: Institute of Chartered Accountants of England and Wales, 1977.

Hayek, F.A. 1945. "The Use of Knowledge in Society," The American Economic Review, Vol. 35:4 (September), pp. 519-530. 
Jarrell, Greg A., James A. Brickley and Jeffrey M. Netter. 1988. "The Market for Corporate Control: The Empirical Evidence Since 1980." Journal of Economic Perspectives 2:1 (Winter), pp. 49-68.

Jensen, Michael C. and Richard S. Ruback. 1983. "The Market for Corporate Control: Scientific Evidence," Journal of Financial Economics 11: pp. 5-50.

Leibenstein, Harvey. 1979. "A Branch of Economics is Missing: Micro-Micro Theory,” Journal of Economic Literature, 17:2 (June), pp. 477-502.

Matsumoto, Toshifumi. 2007. "Social Value of a Corporation," Faculty of Commerce, Doshisha University.

National Association of Accountants. 1974. "Report of the Committee on Accounting for Corporate Social Performance," Management Accounting, (February), pp. 39-41.

Rousseau, Jean Jacque. 1762. The Social Contract. New York: Hafner Publishing Co., 1947.

Scherer, F.M. 1988. "Corporate Takeovers: The Efficiency Arguments," Journal of Economic Perspectives 2:1 (Winter), pp. 69-82.

Seidler, Lee J. 1973. "Dollar Values in the Social Income Statement," World, (Spring). Peat, Marwick, Mitchell \& Co. Reprinted in Seidler and Seidler, eds. Social Accounting: Theory, Issues and Cases. New York: John Wiley, 1975.

Seidler, Lee, and Lynn L. Seidler. 1975. Social Accounting: Theory, Issues and Cases. New York: John Wiley.

Shleifer, Andrei, and Lawrence Summers. 1987. "Hostile Takeovers as Breaches of Trust," NBER Working Paper.

Simon, Herbert A. 1946. Administrative Behavior. New York: Macmillan.

Simon, Herbert A. 1952-53. "A Comparison of Organisation Theories," The Review of Economic Studies, 20:1, pp. 40-48.

Sunder, Shyam. 1997. Theory of Accounting and Control. Cincinnati, OH: Southwestern College Publishing.

Sunder, Shyam. 1999. "Design and Implementation of Contracts: A Comparison of Factor Markets Relevant to Financial Reporting in Japan and the U.S." in Shyam Sunder and Hidetoshi Yamaji, eds., The Japanese Style of Business Accounting, Westport CT: Quorum Books, 1999a, pp. 209-20.

Sunder, Shyam, "Classical, Stewardship and Market Perspectives on Accounting: A Synthesis," in Shyam Sunder and Hidetoshi Yamaji, eds., The Japanese Style of Business Accounting, Westport CT: Quorum Books, 1999b, pp. 17-31.

Sunder, Shyam. 2000. "Accounting: Continuity and Transition," in Gary J. Previts, ed. Research in Accounting Regulation Vol. 14: pp. 229-243. Elsevier Inc.

Williamson, Oliver E. 1975. Markets and Hierarchies: Analysis and Antitrust Implications: A study in the economics of internal organization. New York: Free Press.

Zadek, Simon and Chris Tuppen, "Adding Values: The Economics of Sustainable Business," Institute for Social and Ethical Accountability and BT PLC, May 2000. http://www.groupbt.com/society/index.htm. 